\title{
Temporal variation in fish composition and abundance in a perennial tributary of the rio Paraguaçu, a little-known drainage in the Brazilian semi-arid region
}

\author{
Alexandre Clistenes de A. Santos ${ }^{1}$ and Érica P. Caramaschi ${ }^{2}$
}

The rio Santo Antônio is a perennial lowland stream in the Brazilian semi-arid region, and is the main tributary of the upper rio Paraguaçu, an important drainage of the Chapada Diamantina. The temporal variation of the fish composition and abundance in a stretch of the middle course of the river was evaluated. Sampling was carried out monthly between August 1998 and July 1999, using standardized gear and techniques. Data on water and air temperature, water transparency, maximum and mean depth, width and area of the channel, and flow were recorded on each fish sampling occasion. Univariate and multivariate statistical analyses were employed in order to detect significant temporal differences in environmental parameters and fish abundance. Temperature, transparency and channel depth drove opposite tendencies between the dry and rainy months. The fish community richness (32) and composition did not change between these periods, but large fish caught with gillnets were more abundant in the rainy months. We conclude that the undramatic disturbance in the hydrological stream conditions between the dry and rainy periods led to weak responses of the fish assemblage. Long-term monitoring would be necessary, however, to assess the real persistence of the fish community structure in this perennial stream.

O rio Santo Antônio é um rio perene e de planície do Semi-árido brasileiro, sendo o principal tributário do alto curso do rio Paraguaçu, importante componente da bacia de drenagem da Chapada Diamantina. Neste trabalho foi avaliada a variação temporal na composição e abundância da ictiofauna em um trecho de seu médio curso. As amostras foram realizadas mensalmente entre agosto de 1998 e julho de 1999, utilizando-se apetrechos e artes de pesca padronizadas. Juntamente com a coleta dos peixes foram tomados os parâmetros ambientais de temperatura da água e do ar, transparência da água, profundidade máxima e média, largura e área do canal e velocidade da corrente. Análises estatísticas univariadas e multivariadas foram utilizadas visando detectar diferenças temporais significativas na abundância das espécies e nos parâmetros ambientais. A temperatura, a transparência e a profundidade do canal mostraram tendências opostas entre os períodos seco e chuvoso. A riqueza da comunidade de peixes (32) e a composição não variaram entre os dois períodos, entretanto espécies de maior porte capturadas por redes-de-espera foram mais abundantes no período chuvoso. Nós concluímos que as poucas mudanças nas condições hidrológicas do rio entre os dois períodos levaram a uma fraca resposta da comunidade de peixes local. Monitoramentos de longo prazo serão necessários pra acessar a real persistência da estrutura da comunidade de peixes neste rio perene do Semi-árido brasileiro.

Key words: Chapada Diamantina, Ichthyofauna, Richness, Seasonality.

\section{Introduction}

The rio Paraguaçu occupies one of the most extensive basins of the Brazilian Northeast region. It rises in the Chapada Diamantina, central region of the State of Bahia and discharges into the Todos os Santos Bay (Atlantic Ocean). The rio Paraguaçu is a perennial river that receives several intermittent tributaries in the semi-arid region, being dammed for the Pedra do Cavalo hydroelectric plant in its lower course. Until 1990, knowledge of the fish fauna of the rio Paraguaçu was considered sparse by Higuchi et al. (1990), but de Pinna (1992) noted the rich and endemic ichthyofauna in the basin headwaters. Fish sampling carried out between 1998 and 1999 in several localities in the upper course showed a diversified assemblage (Santos, 2003; Santos \& Caramaschi, 2007) and revealed several recently described and undescribed species (Higuchi et al., 1990; de Pinna, 1992; Campanario \& de Pinna, 2000; Lima \& Gerhard, 2001; Zanata \& Akama, 2004; Britto et al., 2005; Benine et al., 2007; Birindelli et al., 2007). The definition of a new subfamily for a small endemic catfish of the Chapada Diamantina (de Pinna, 1992) included specimens from the headwaters of the rio Paraguaçu.

${ }^{1}$ Laboratório de Ictiologia, Departamento de Ciências Biológicas, Universidade Estadual de Feira de Santana. 44036-900 Feira de Santana, BA, Brazil. alexandreclistenes@gmail.com

${ }^{2}$ Laboratório de Ecologia de Peixes, Departamento de Ecologia, IB, UFRJ. Cx. Postal 68020, Ilha do Fundão 21941-590, Rio de Janeiro, RJ, Brazil.ericacaramaschi@ufrj.br 
From the $19^{\text {th }}$ century until 1980 , the rivers of the Chapada Diamantina were disturbed by diamond mining. This exploitation caused dramatic changes along the riverbanks, from the burning of the riparian vegetation and dumping of used oil. The riverbed and flow dynamics were profoundly modified by the formation of large deep pools (locally termed "catras"). Nowadays, the threats to the stream biota of the Chapada Diamantina National Park are deforestation and nonsustainable practices of ecological and adventure tourism. However, little information exists about the status and resilience of the fish fauna (Santos, 2003; Santos \& Caramaschi, 2007).

The rio Santo Antônio is the main tributary of the upper course of the rio Paraguaçu, and crosses lowlands on the east side of the Chapada Diamantina National Park until it discharges into the rio Paraguaçu. Considering that the rainy period in general brings an increase of water volume and allochthonous resources, it is reasonable to suppose that the fish assemblage will respond to these cyclical conditions. In this study, we assessed the variation in the composition and abundance of the fish fauna of the middle rio Santo Antônio, related to environmental parameters in the rainy and dry periods.

\section{Material and Methods}

\section{Study area}

The rio Santo Antônio is around $100 \mathrm{~km}$ long (Fig. 1), and varies in altitude from 600 to $400 \mathrm{~m}$ between headwaters and mouth. The 200-m-long river stretch studied $\left(12^{\circ} 39^{\prime} 37^{\prime \prime} \mathrm{S} 41^{\circ} 19^{\prime} 43^{\prime \prime} \mathrm{W}\right)$ is a $6^{\text {th }}$-order channel (sensu Strahler, 1957), with riparian vegetation composed by forest and cultivated land. The mean width is $22.6 \mathrm{~m}$ and the maximum depth is $4 \mathrm{~m}$.

\section{Sampling procedures}

Fish and environmental parameters were sampled monthly between August 1998 and July 1999. The air and water temperatures (thermometer), water transparency (Secchi disk), maximum and mean depth, width (tape measure) and area (calculed from width and depth) of channel and flow were recorded. Monthly rainfall data for the study

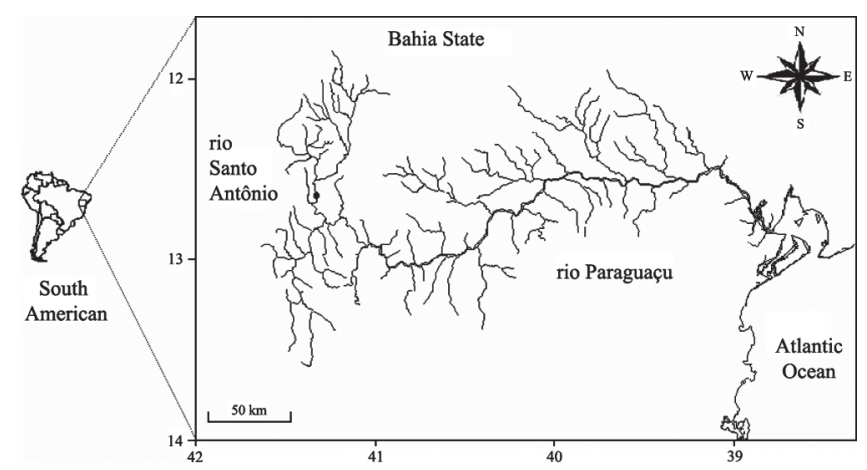

Fig. 1. Geographical location of the rio Paraguaçu drainage and of the sampling stretch in the rio Santo Antônio (black dot). period were obtained at the meteorological station of the Lençóis municipality and compared with a 10-year historical series, confirming a local seasonal pattern (Santos \& Novaes, 2008). The monthly sampling data were grouped into two periods: November to March (rainy) and April to October (dry).

The fish were caught with a standardized capture effort. Gillnets, a cast seine, and a handnet were used along the river stretch to sample open-water and near-bank habitats. Three gillnets with mesh size between $30 \mathrm{~mm}$ and $60 \mathrm{~mm}$ knot-to-knot were used, for a mean effort of $167 \mathrm{~m}^{2} / 24 \mathrm{~h}$ on each sampling, checked four times per day. A 12-m diameter and $2-\mathrm{cm}$ mesh size cast seine and $38-\mathrm{cm}$ diameter and $0.3-$ $\mathrm{cm}$ mesh size handnet were worked for one hour on each sampling, in the morning, midday and evening. A $38-\mathrm{cm}$ diameter and $0.3-\mathrm{cm}$ mesh size handnet was used for one hour on each sampling occasion, also in the morning, midday, and evening.

The fish were fixed in $4 \%$ formaldehyde and later preserved in $70 \%$ ethanol. Species were identified based on literature sources and by comparison with the collections at the Museu Nacional do Rio de Janeiro (MNRJ) and the Museu de Zoologia da Universidade de São Paulo (MZUSP). Specialists in some of the groups were also consulted. The taxonomic classification of Reis et al. (2003) was adopted. Voucher specimens were deposited in the Museu Nacional/ Universidade Federal do Rio de Janeiro under the following registers: MNRJ 21754 Acestrorhynchus lacustris; MNRJ 22059; MNRJ 21771; MNRJ 21783; MNRJ 21779; MNRJ 21761 Astyanax bimaculatus; MNRJ 22093; MNRJ 22096; MNRJ 22094; MNRJ 22098; MNRJ 22088; MNRJ 21762 Astyanax fasciatus; MNRJ 22695; MNRJ 22672; MNRJ 22706; MNRJ 22704; MNRJ 23804; MNRJ 21989 Astyanax sp.; MNRJ 23754; MNRJ 22082 Characidium bahiensis; MNRJ 22085; MNRJ 23786 Characidium cf. bimaculatum; MNRJ 21809 Cichla ef pinima; MNRJ 21799 Cyphocharax gilberti; MNRJ 21786; MNRJ 21787 Gymnotus carapo; MNRJ 22052; MNRJ 22054; MNRJ 22056; MNRJ 22058; MNRJ 22051 Hemigrammus marginatus; MNRJ 21917; MNRJ 21919; MNRJ 21921; MNRJ 21969 Hoplias lacerdae; MNRJ 21960; MNRJ 21904; MNRJ 21911; MNRJ 21915; MNRJ 21951; MNRJ 21964 Hoplias malabaricus; MNRJ 22760; MNRJ 22755; MNRJ 22761; MNRJ 22747 Hyphessobrycon negodagua; MNRJ 21947; MNRJ 21942 Hypostomus chrysostiktos; MNRJ 21720; MNRJ 21723; MNRJ 21713; MNRJ 21714 Leporinus sp.; MNRJ 21701; MNRJ 21704; MNRJ 21693 Pamphorichthys hollandi; MNRJ 21752; MNRJ 21753; MNRJ 21751 Parauchenipterus galeatus; MNRJ 21940 Rhamdia quelen; MNRJ 22067; MNRJ 22074 Serrapinnus heterodon; MNRJ 22062; MNRJ 22070; MNRJ 22069; MNRJ 22061 Serrapinnus piaba; MNRJ 21727 Serrasalmus brandtii; MNRJ 21803; MNRJ 21794; MNRJ 21798 Steindachnerina elegans; MNRJ 21929; MNRJ 21931; MNRJ 21932; MNRJ 21933; MNRJ 21925; MNRJ 21926 Tetragonopterus chalceus. Common names were recorded in loco and/or provided by Flávia de B. P. Moura. 


\section{Data analysis}

The fish species were ranked for each type of sampling gear by the Index of Relative Importance (IRI), as used by Beaumord (1991). This method combines weight (Pi), number $(\mathrm{Ni})$, and frequency of occurrence $(\mathrm{C}): \mathrm{IIR}=(\mathrm{NiPiC} / \Sigma \mathrm{NiPiC}) \mathrm{x}$ 100. Each species was classified as constant, accessory, or rare according to the frequency of occurrence values (sensu Dajoz, 1978). Because the capture effort was standardized for each type of gear, the simple number of individuals was considered the fish abundance value. The abundance values of the five most important species (defined by the IRI) at least one type of sampling gear were related to environmental variables in a canonical correspondence analysis (CCA), to assess environmental influences on the fish assemblages. This ordination method is a powerful multivariate technique to describe how multiple species respond simultaneously to environmental factors and is designed to extract synthetic environmental gradients from ecological data sets (ter Braak 1991). Rare species, e.g., those that constituted a low percentage of the fish importance were not considered in this multivariate analyses.

The data for environmental variables and fish abundance were log-transformed $(x+1)$ to meet the assumptions of normality and homoscedasticity for univariate and multivariate tests, to reduce the weight of abundant species, and to balance the effect of different measurement units of environmental factors. Statistical significance was assessed at a $<0.05$. Multiple regression analysis (Zar, 1984) and in absence of normality or variance homogeneity Spearman rank correlation coefficient were used to determine the significance of each environmental variable in determining the fish abundance. The first analysis determines the independent variables most likely to affect the distribution of each species together with the nature of the effect while the second analysis is used to test the relationships between fish population abundance and environmental variables (Araújo et al., 1999). Multiple regression analysis and Spearman rank correlation were carried out using the GraphPad InStat v.3.0 software. For the canonical correspondence analysis was used Canoco for Windows v.04.

\section{Results}

Significant differences between the dry and rainy periods were found for temperature, transparency, and maximum depth in the rio Santo Antônio. Air and water temperature and maximum water depth were higher in the rainy period; transparency was higher in the dry period. The mean depth and the area were not significantly higher in the rainy period. No seasonal tendency was observed for width of channel and flow (Table 1).

A total 3,044 fishes $(32,500 \mathrm{~g})$ were collected. Thirty-two species, 14 families and five orders were recorded in this middle stretch of the river (Table 2), with predominance of Characiformes (70\%). The species recorded by type of fishing gear, the total number of individuals caught, frequency of occurrence, the relative importance of each species (IRI, in decreasing order) are shown in Table 3.
The following species, which showed high IRI values for at least one type of sampling gear, were included in the analysis: Hoplias malabaricus, Leporinus bahiensis, Parauchenipterus galeatus, Prochilodus costatus, Serrasalmus brandtii, Steindachnerina elegans, Tetragonopterus chalceus, Geophagus brasiliensis, Serrapinnus heterodon, Pamphorichthys hollandi, Astyanax sp., Astyanax gr. bimaculatus, and Serrapinnus piaba. Only L. bahiensis and S. brandtii showed high IRI values for more than one type of gear.

The multiple regression analysis showed that the abundance of $S$. heterodon was positively related to water temperature and negatively to air temperature. The abundance of $P$. costatus, on the other hand, was positively related to air temperature and negatively related to water temperature and maximum depth of the channel. The high abundance of specimens of $S$. brandtii caught by gillnets, in turn, was positively related to the transparency, water temperature, channel width, and mean depth, and negatively related to the area (Table 4).

The Spearman rank correlation (Table 5) showed that, in samples with handnets, the abundance of $P$. hollandi decreased with increasing air temperature and increased with the width of the river. Astyanax sp. was more abundant in increased air temperature, whereas S. piaba was more abundant in decreased water temperature. The abundance of $S$. elegans captured with cast nets rise with increased transparency, and with depth and area decreasing. Geophagus brasiliensis, in turn, showed high abundance in water of low depth. For species caught with gillnets, the abundances of $H$. malabaricus and L. bahiensis increased in high air temperatures. Parauchenipterus galeatus, in turn, showed high abundance in increasing water temperature, and the abundance of $P$. costatus decreased when the depth increased.

The canonical correspondence analysis (CCA) revealed that water temperature and maximum depth were the environmental variables that were significantly correlated with fish abundance (Table 6). The correlation between species and environmental variables was 0.984 for the first axis and 0.943 for the second one. In accordance with these coefficients, the first axis corresponded to the gradient of

Table 1. Mean values of the environmental variables in the rainy and dry periods, non-parametric test of Kruskal-Wallis and "a posteriori" Dunn's test for environmental variables between the analyzed periods.

\begin{tabular}{lccccc}
\hline Environmental variables & Rain & Dry & $\mathrm{p}$ & Kruskal-Wallis & Dunn \\
\hline Water temperature $\left({ }^{\circ} \mathrm{C}\right)$ & 27.5 & 24.4 & 0.0001 & $110.08^{* *}$ & rainy $>$ dry \\
Air temperature $\left({ }^{\circ} \mathrm{C}\right)$ & 25.4 & 23.9 & 0.0037 & $13.474^{* *}$ & rainy $>$ dry \\
Transparency $(\mathrm{m})$ & 1.4 & 2.1 & 0.0001 & $121.54^{* *}$ & dry $>$ rainy \\
Maximum depth $(\mathrm{m})$ & 3.5 & 3.3 & 0.0041 & $13.274^{* *}$ & rainy $>$ dry \\
Mean depth $(\mathrm{m})$ & 2.6 & 2.3 & 0.0897 & 6.500 & --- \\
River width $(\mathrm{m})$ & 24.6 & 24.2 & 0.8875 & 0.639 & --- \\
Area $\left(\mathrm{m}^{2}\right)$ & 31.0 & 26.7 & 0.5296 & 2.212 & --- \\
Flow $(\mathrm{m} / \mathrm{s})$ & 0.123 & 0.122 & 0.1264 & 5.714 & --- \\
\hline
\end{tabular}


Table 2. List of species, families, and orders of fishes recorded in the middle rio Santo Antônio between August 1998 and July 1999 (according to Reis et al., 2003).

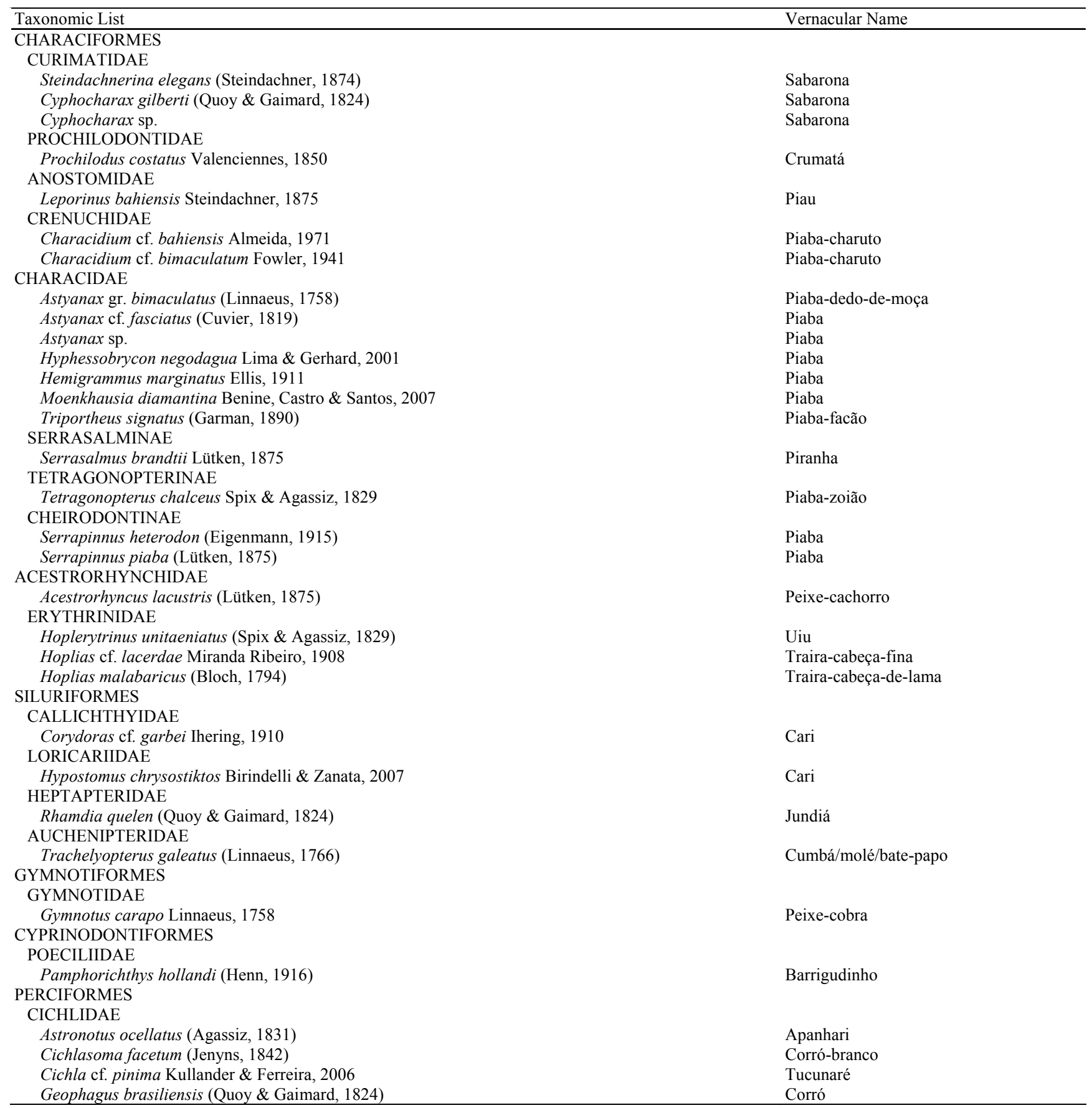

transparency, depth, and area, while the second axis corresponded to the gradients of air and water temperature. The two axes combined accounted for $55.2 \%$ of the environmental influence on the fish abundance in the rio Santo Antônio (Table 6).

Axis 1 explained $35.3 \%$ of the variation in speciesenvironmental variables, and separated the months of the rainy period on the left side, characterized by deeper water, in contrast to the months of the dry period on the right side, characterized by shallower water. The major source of variation in the data was a shift in the fish community structure between the rainy period (November to March) and the dry period (October to April), along axis 1, coincident with the seasonal difference in water depth. Prochilodus costatus, G. brasiliensis, and S. piaba were associated with shallower depths, while L. bahiensis, $A$. lacustris, and $P$. hollandi were associated with deep water (Fig. 2). 
Table 3. Number (N), Frequency of ocurrence (FO), and Index of Relative Importance (IRI) for fish caught in the middle rio Santo Antônio, by gillnet, cast seine, and handnets. $\mathrm{C}=$ Constant, $\mathrm{A}=$ Acessor, and $\mathrm{R}=$ Rare .

\begin{tabular}{|c|c|c|c|c|c|c|c|c|c|c|c|}
\hline \multirow{2}{*}{$\begin{array}{l}\text { GILLNET } \\
\text { Species }\end{array}$} & & & & \multicolumn{4}{|l|}{ CAST SEINE } & \multicolumn{4}{|l|}{ HANDNETS } \\
\hline & $\mathrm{N}$ & FO & IRI & Species & $\mathrm{N}$ & FO & IRI & Species & $\mathrm{N}$ & FO & IRI \\
\hline H. malabaricus & 38 & $\mathrm{C}$ & 46.76 & S. elegans & 201 & $\mathrm{C}$ & 69.40 & S. heterodon & 666 & $\mathrm{C}$ & 55.52 \\
\hline L. bahiensis & 20 & $\mathrm{C}$ & 15.66 & T. chalceus & 108 & $\mathrm{C}$ & 12.00 & P. hollandi & 552 & $\mathrm{C}$ & 21.64 \\
\hline P. galeatus & 18 & $\mathrm{C}$ & 12.08 & S. brandtii & 92 & $\mathrm{C}$ & 8.83 & Astyanax sp. & 280 & $\mathrm{C}$ & 9.06 \\
\hline P. costatus & 13 & $\mathrm{C}$ & 8.72 & G. brasiliensis & 46 & $\mathrm{C}$ & 6.38 & A. bimaculatus & 215 & $\mathrm{C}$ & 6.51 \\
\hline S. brandtii & 10 & $\mathrm{C}$ & 7.83 & L. bahiensis & 30 & $\mathrm{C}$ & 1.95 & S. piaba & 120 & $\mathrm{C}$ & 2.54 \\
\hline H. cf. lacerdae & 9 & A & 4.03 & C. gilberti & 30 & $\mathrm{C}$ & 0.82 & H. negodagua & 135 & $\mathrm{C}$ & 1.68 \\
\hline G. brasiliensis & 7 & A & 3.13 & A. lacustris & 13 & $\mathrm{C}$ & 0.47 & C. cf. garbei & 70 & $\mathrm{R}$ & 1.29 \\
\hline C. cf. pinima & 2 & $\mathrm{R}$ & 0.45 & P. costatus & 8 & A & 0.11 & G. brasiliensis & 28 & $\mathrm{C}$ & 1.03 \\
\hline G. carapo & 2 & $\mathrm{R}$ & 0.45 & H. malabaricus & 5 & A & 0.02 & T.chalceus & 47 & $\mathrm{C}$ & 0.42 \\
\hline H. chrysostiktos & 2 & $\mathrm{R}$ & 0.45 & A.bimaculatus & 16 & A & 0.02 & H. cf. lacerdae & 18 & $\mathrm{C}$ & 0.19 \\
\hline A. lacustris & 3 & $\mathrm{R}$ & 0.34 & A. cf. fasciatus & 7 & A & $<0.01$ & H. malabaricus & 8 & A & 0.07 \\
\hline A. ocellatus & 1 & $\mathrm{R}$ & 0.11 & S.piaba & 11 & $\mathrm{C}$ & $<0.01$ & C. cf. bahiensis & 15 & $\mathrm{C}$ & 0.02 \\
\hline \multirow[t]{12}{*}{ TOTAL } & 125 & & & T. signatus & 1 & A & $<0.01$ & C. facetum & 4 & $\mathrm{R}$ & 0.01 \\
\hline & & & & Astyanax sp. & 4 & A & $<0.01$ & H. unitaeniatus & 7 & $\mathrm{R}$ & 0.01 \\
\hline & & & & S. heterodon & 2 & $\mathrm{R}$ & $<0.01$ & H. marginatus & 8 & A & $<0.01$ \\
\hline & & & & Cyphocarax sp. & 1 & $\mathrm{R}$ & $<0.01$ & C. cf. bimaculatum & 8 & A & $<0.01$ \\
\hline & & & & H. marginatus & 1 & $\mathrm{R}$ & $<0.01$ & A. cf. fasciatus & 4 & $\mathrm{R}$ & $<0.01$ \\
\hline & & & & C. cf. bimaculatum & 1 & $\mathrm{R}$ & $<0.01$ & Cyphocarax sp. & 5 & $\mathrm{R}$ & $<0.01$ \\
\hline & & & & TOTAL & 577 & & & M. diamantina & 2 & $\mathrm{R}$ & $<0.01$ \\
\hline & & & & & & & & L. bahiensis & 10 & $\mathrm{R}$ & $<0.01$ \\
\hline & & & & & & & & S. brandtii & 8 & $\mathrm{R}$ & $<0.01$ \\
\hline & & & & & & & & S. elegans & 1 & $\mathrm{R}$ & $<0.01$ \\
\hline & & & & & & & & C. gilberti & 1 & $\mathrm{R}$ & $<0.01$ \\
\hline & & & & & & & & TOTAL & 2212 & & \\
\hline
\end{tabular}

Axis 2 explained $19.9 \%$ of the variation in speciesenvironmental variables, and separated the rainy-season months in the lower part of the diagram, characterized by higher water temperatures, in opposition to the dry-season months in the upper part of the diagram. The species closely associated with high water temperature, and distributed in the lower part of the diagram were P. costatus, P. galeatus, L. bahiensis, S. brandtii, A. lacustris, and Astyanax sp. The species in the upper part of the diagram and associated with low water temperature were H. malabaricus, S. piaba, and P. hollandi (Fig. 2).

\section{Discussion}

Despite the large number of studies carried out in recent years on the ichthyofauna of South America, the ecology of the fishes of the Brazilian Northeast region is still poorly known. Studies of the ichthyofauna of the rio Santo Antônio have been recently reported. After the fish species composition list of Santos (2003), two species (Moenkhausia diamantina Benine, Castro \& Santos, 2007 and Hypostomus chrysostiktos Birindelli, Zanata \& Lima, 2007 were described from this drainage. Of ten species recently described from Chapada Diamantina localities, only Hyphessobrycon negodagua, $H$. chrysostiktos, and $M$. diamantina were recorded in the rio Santo Antônio itself. The others occur in higher localities, in small streams 3-4 m wide (Santos, 2003; Santos \& Caramaschi, 2007).

The species list for the rio Santo Antônio includes three introduced species (Astronotus ocellatus, Cichla cf. pinima, and Triportheus signatus) originating from other South American

Table 4. Regression analysis between fish abundance and environmental variables in the rio Santo Antônio.* Correlations significant at $\mathrm{p}<0,05 ; * *$ Correlations significante at $\mathrm{p}<0,01 ; \mathrm{n} . \mathrm{s} .=$ not significant.

\begin{tabular}{|c|c|c|c|c|c|c|c|c|}
\hline Equipament & Species & Transparency & Water temp. & Air temp. & Max. depth & Mean depth & Area & Width \\
\hline \multirow[t]{5}{*}{ Handnets } & S. heterodon & n.s. & $5.09 *$ & $-3.63 *$ & n.s. & n.s. & n.s. & n.s. \\
\hline & P. hollandi & n.s. & n.s. & n.s. & n.s. & n.s. & n.s. & n.s. \\
\hline & Astyanax sp. & n.s. & n.s. & n.s. & n.s. & n.s. & n.s. & n.s. \\
\hline & A. gr. bimaculatus & n.s. & n.s. & n.s. & n.s. & n.s. & n.s. & n.s. \\
\hline & S. piaba & n.s. & n.s. & n.s. & n.s. & n.s. & n.s. & n.s. \\
\hline \multirow[t]{5}{*}{ Cast seine } & S. elegans & n.s. & n.s. & n.s. & n.s. & n.s. & n.s. & n.s. \\
\hline & T. chalceus & n.s. & n.s. & n.s. & n.s. & n.s. & n.s. & n.s. \\
\hline & S. brandtii & n.s. & n.s. & n.s. & n.s. & n.s. & n.s. & n.s. \\
\hline & G. brasiliensis & n.s. & n.s. & n.s. & n.s. & n.s. & n.s. & n.s. \\
\hline & L. bahiensis & n.s. & n.s. & n.s. & n.s. & n.s. & n.s. & n.s. \\
\hline \multirow[t]{5}{*}{ Gillnets } & H. malabaricus & n.s. & n.s. & n.s. & n.s. & n.s. & n.s. & n.s. \\
\hline & L. bahiensis & n.s. & n.s. & n.s. & n.s. & n.s. & n.s. & n.s. \\
\hline & P. galeatus & n.s. & n.s. & n.s. & n.s. & n.s. & n.s. & n.s. \\
\hline & P. costatus & n.s. & $-8.94 * *$ & 5.16 & $-11.99 * *$ & n.s. & n.s. & n.s. \\
\hline & S. brandtii & $3.52 *$ & $3.24 *$ & n.s. & n.s. & $5.21 *$ & $-5.35^{*}$ & $5.38 *$ \\
\hline
\end{tabular}


Table 5. Spearman Rank correlation between fish abundance and environmental variables in the rio Santo Antônio. * Correlations significant at $\mathrm{p}<0,05 ; * *$ Correlations significante at $\mathrm{p}<0,01 ;$ n.s. $=$ not significant.

\begin{tabular}{|c|c|c|c|c|c|c|c|c|}
\hline Equipament & Species & Transparency & Water temp. & Air temp. & Max. depth & Mean depth & Area & Width \\
\hline \multirow[t]{5}{*}{ Handnets } & S. heterodon & n.s. & n.s. & n.s. & n.s. & n.s. & n.s. & n.s. \\
\hline & P. hollandi & n.s. & n.s. & $-0.76 * *$ & n.s. & n.s. & n.s. & $0.63 *$ \\
\hline & Astyanax sp. & n.s. & n.s. & $0.65 *$ & n.s. & n.s. & n.s. & n.s. \\
\hline & A. lacustris & n.s. & n.s. & n.s. & n.s. & n.s. & n.s. & n.s. \\
\hline & S. piaba & n.s. & $-0.73 * *$ & n.s. & n.s. & n.s. & n.s. & n.s. \\
\hline \multirow[t]{5}{*}{ Cast seine } & S. elegans & $0.71 *$ & n.s. & n.s. & $-0.69^{*}$ & $-0.65^{*}$ & $-0.75 * *$ & n.s. \\
\hline & T. chalceus & n.s. & n.s. & n.s. & n.s. & n.s. & n.s. & n.s. \\
\hline & S. brandtii & n.s. & n.s. & n.s. & n.s. & n.s. & n.s. & n.s. \\
\hline & G. brasiliensis & n.s. & n.s. & n.s. & n.s. & $-0.76 * *$ & n.s. & n.s. \\
\hline & L. bahiensis & 0.8 & n.s. & n.s. & n.s. & n.s. & n.s. & n.s. \\
\hline \multirow[t]{5}{*}{ Gillnets } & H. malabaricus & n.s. & n.s. & $0.72 * *$ & n.s. & n.s. & n.s. & n.s. \\
\hline & L. bahiensis & n.s. & n.s. & $0.62 * *$ & n.s. & n.s. & n.s. & n.s. \\
\hline & P. galeatus & n.s. & $0.80 * *$ & n.s. & n.s. & n.s. & n.s. & n.s. \\
\hline & P. costatus & n.s. & n.s. & n.s. & $-0.75 * *$ & n.s. & n.s. & n.s. \\
\hline & S. brandtii & n.s. & n.s. & n.s. & n.s. & n.s. & n.s. & n.s. \\
\hline
\end{tabular}

basins. Winemiller et al. (2008) noted the importance of interbasin transfer of non-indigenous fishes as a prevalent problem in tropical rivers. The introduced species in the rio Santo Antonio are esteemed by local fishermen, but they really are a kind of biological pollution and are the second major cause of extinction of native species (Lowe-McConnell, 1999; Winemiller et al., 2008). The introduction of peacock cichlids (Cichla spp.) into Central and South American rivers has caused serious alterations in fish communities (e.g., Zaret \& Paine, 1973; Jepsen et al., 1997; Latini \& Petrere, 2004; Winemiller et al., 2008). Pompeu \& Godinho (2001) observed changes in the diet of Hoplias malabaricus in the rio Doce after the introduction of two species of piscivorous fishes. Differences in the diet of $H$. malabaricus were also found by Santos (2003), comparing a river where Cichla $\mathrm{cf}$. pinima was introduced, and a river still maintaining a native community in the Rio Paraguaçu basin. Hoplias malabaricus showed highest proportion in the consumption of insects in their diet under these conditions.

The region studied has a tropical climate with distinct dry and rainy periods. We observed seasonal variation in the main environmental variables analyzed, with significant differences in temperature and maximum depth (high in the rainy period) and in transparency (high in the dry period). The local topographic characteristics of low declivity and extensive flat areas may explain the small difference in the mean depths in the dry and rainy periods. Maltchik (1999) noted that the influence of hydrological disturbances on ecosystem organization is less in the perennial streams of the Brazilian semiarid region than in intermittent streams.

In tropical rivers, the fish communities are affected by seasonal changes, due to the expansion of the aquatic environment from the dry to the rainy season. In consequence, the species composition tends to change in accordance with the time of year and with the volume of water (LoweMcConnell, 1999; Fernandes et al., 2009).

In Brazilian semiarid streams, Medeiros \& Maltchik (2001) described the dominance of a few species mainly in the dry season, when the input of other species or individuals is reduced. In our study, the fish fauna was dominated by a few species that were caught in all the sampling gear used in both seasons, rainy and dry. Such dominance is the main factor that reduces the fish diversity in perennial streams in the semiarid region (Medeiros \& Maltchik, 2001).

We used the constancy analysis, a qualitative method that indicates the existence of resident or migratory species (e.g., Pavanelli \& Caramaschi, 1997), and also the seasonal changes in the community (Uieda, 1984). Half of the species (16) occurred year-round in the rio Santo Antônio. They were constant species as caught by least one sampling method; only $S$. brandtii and L. bahiensis were constant in two types of sampling gear (gillnet and cast seine).

Our results provided evidence of the selectivity of the different types of sampling gear, and pointed to the importance of using multiple fish-capture techniques in this perennial river. The gillnets caught large fish $(12-45 \mathrm{~cm} \mathrm{SL})$ such as adults of $L$. bahiensis, $P$. costatus, $P$. galeatus, and H. lacerdae (Santos, 2003). The medium-sized S. elegans (14 cm, according to Santos, 2003) was not caught by

Table 6. Summary of the canonical correspondence analysis of the abundance of fish species.

\begin{tabular}{lll}
\hline Axes & 1 & 2 \\
\hline Transparency & 0.5396 & 0.0273 \\
Water temperature & 0.4235 & 0.7494 \\
Air temperature & 0.1047 & 0.7058 \\
Maximun depth & 0.7912 & 0.0821 \\
Area & 0.5382 & 0.0045 \\
Width & 0.3091 & 0.2671 \\
Mean depth & 0.5667 & 0.1876 \\
Eigenvalues & 0.265 & 0.149 \\
Species-environmental correlations & 0.984 & 0.943 \\
Cumulative percentage of variance & & \\
of species data & 27.4 & 42.9 \\
of species-environmental correlations & 35.3 & 55.2 \\
Sum of all unconstrained eigenvalues & & 0.967 \\
Sum of all canonical eigenvalues & & 0.751 \\
Significance test of first canonical axis: & & eigenvalues $=0.265$ \\
$\mathrm{~F}=1.513$ & & \\
$\mathrm{p}=0.735$ & & \\
Significance test for all canonical axes: & & trace $=0.751$ \\
$\mathrm{~F}=1.992$ & & \\
$\mathrm{p}=0.080$ & & \\
\hline
\end{tabular}




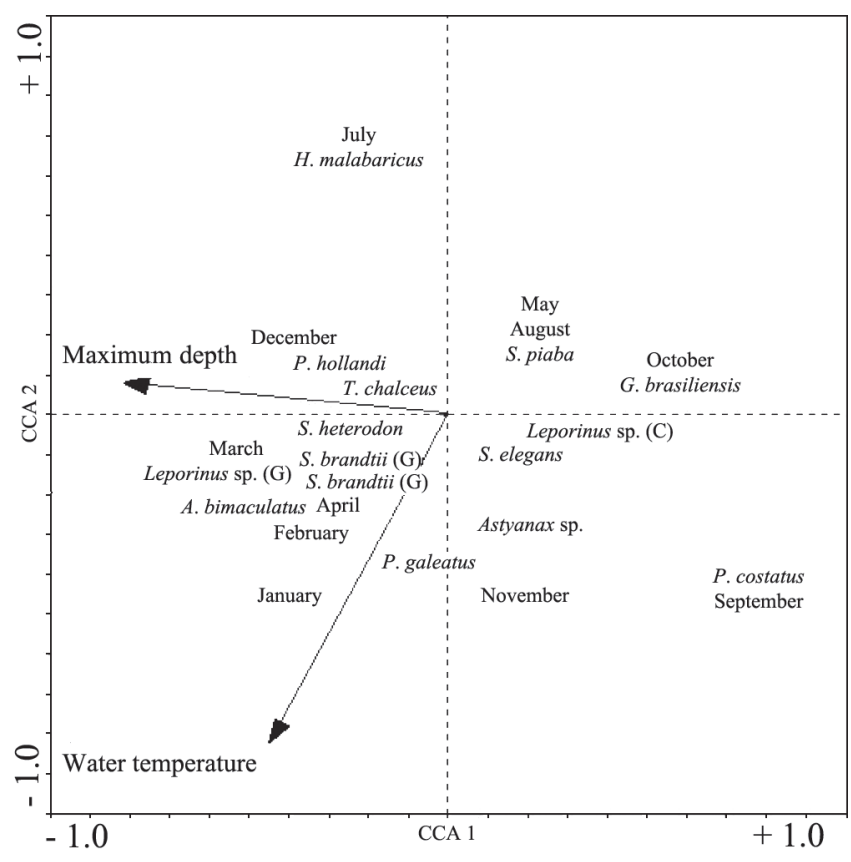

Fig. 2. Canonical correspondence analysis ordination diagram of fish abundance data, with environmental variables, for the rainy period (November to March) and the dry period (April to October). $\mathrm{G}=$ Gillnet; $\mathrm{C}=$ Cast seine.

gillnets, possibly due to its fusiform body which allows the fish to pass through the nets. The handnets caught only small-sized fish (characids and poeciliids less than $9 \mathrm{~cm} \mathrm{SL}$, according to Santos, 2003) near the riverbanks. The cast seine, used in open areas at different depths, was the most versatile sampling gear, capturing specimens of 18 species ( $56 \%$ of the total) of different sizes.

The differences between the composition of the assemblages caught in the two periods were minor, and can be explained by the availability of microhabitats in the rainy period in consequence of the flooding of marginal areas. Mazzoni et al. (2006) also found few temporal differences along the course of a tropical Brazilian river, either in species composition or in environmental characteristics. Variations in abundance may reflect changes in the assemblage structure and/or in the selectivity of sampling gear. Significant differences in abundance values between the rainy and dry periods resulted from greater capture rates of H. malabaricus, L. bahiensis, and P. galeatus by gillnets in the rainy period. Using the same sampling gear, Carvalho et al. (2005) also observed significant differences between the dry and rainy seasons only for samples captured with gillnets, in a lake in the rio Paraná basin. Possibly gillnets are the best gear to detect temporal variation in the fish assemblage structure when the drainage contains migratory species.

The incidence of capture of the large dominant species by gillnets in the main channel of the rio Santo Antônio during the rainy season is confirmed by data from local traditional fishermen. Increased capture of L. bahiensis, $P$. costatus, $S$. elegans, and $P$. galeatus during the rainy season is reported by local fishermen, according to Moura $\&$ Marques (2007). In the dry period, the same authors reported a change in the fishery, which was strategically concentrated in isolated lagoons where the fish were easier to catch.

The environmental variables (temperature and depth) selected in the canonical correspondence analysis (CCA) may elucidate the differences between the rainy and dry periods. Several studies have utilized the CCA to document the relationship between fish species distribution and environmental variables in tropical regions (e.g., Carvalho et al., 2005; Lin \& Caramaschi, 2005; Mazzoni et al., 2006). In this study, the statistical analyses indicated a tendency to seasonality in the environmental variables; however, few species responded to this driver. Temperature and depth were the most important factors associated with the fish distribution, and showed opposite tendencies in the dry and the rainy periods, respectively. Nevertheless, our results showed that small-sized species were less influenced by the river hydrological regime than were the large ones, caught by gillnets.

In this study, a promising line of investigation in fish ecology was evidenced by the high selectivity in captures, suggesting spatial segregation of fish and high habitat diversity. Our study provides a first insight into the response of the ichthyofauna in a perennial stream in a semiarid region, to different seasonal conditions. We found that the nucleus of small species in the fish assemblage of the rio Santo Antônio was stable in composition and abundance in the dry and rainy seasons. The nucleus of large species was stable in composition but changed in abundance, perhaps as a result of the migration of individuals of rheophilic species such as L. bahiensis and $P$. costatus. However, only a long-term monitoring program will be able to demonstrate the real stability of the fish community and its sustainability in the face of natural and human disturbances in the Brazilian semiarid region.

\section{Acknowledgements}

We thank Capes/PICDT for providing a grant to support part of this study. We also thank Gustavo Nunan of the Museu Nacional, Rio de Janeiro (MNRJ) for granting access to the facilities of the Division of Ichthyology during this study. To Flávio Lima (MZUSP), Paulo Buckup and Marcelo Britto (MNRJ) for helping with species identification. To the Projeto Nordeste de Pesquisa/CNPq and to UEFS for support for field activities, and to Flávia de B. P. Moura for providing the common names of some fish species. To Décio Ferreira de Moraes Jr. (MNRJ/UFRJ), Marconi P. Sena, Edjane Santos, Manina Kowalsk, and Benedito Marques (UEFS) for help in the sampling and/or in the laboratory work, to Márcia Azevedo (UFRRJ) for support in the statistical analysis and to Dr. Janet W. Reid for emending the English text. 


\section{Literature Cited}

Araújo, F. G., R. G. Bailey, W. P. Williams. 1999. Spatial and temporal variations in fish populations in the upper Thames estuary. Journal of Fish Biology, 55: 836-853.

Beaumord, A. C. 1991. As comunidades de peixes do rio Manso. Chapada dos Guimarães, MT: Uma abordagem ecológica numérica. Unpublished Ph.D. Dissertation. Instituto de Biociências Carlos Chagas. UFRJ, 108p.

Benine, R. C., R. M. C. Castro \& A. C. A. Santos. 2007. A new Moenkhausia Eigenmann, 1903 (Ostariophysi: Characiformes) from Chapada Diamantina, rio Paraguaçu Basin, Bahia, Northeastern Brazil. Neotropical Ichthyology, 5(3): 259-262.

Birindelli, J. L., A. M. Zanata \& F. C. T. Lima. 2007. Hypostomus chrysostiktos, a new species of armored catfish (Siluriformes: Loricariidae) from rio Paraguaçu, Bahia State, Brazil. Neotropical Ichthyology, 5(3): 271-278.

Britto, M. R., F. C. T. Lima \& A. C. A. Santos. 2005. A new Aspidoras (Siluriformes: Callichthyidae) from rio Paraguaçu basin, Chapada Diamantina, Bahia, Brazil. Neotropical Ichthyology, 3(4): 473-479.

Campanario, C. M. \& M. C. C. de Pinna. 2000. A new species of the primitive trichomycterid subfamily Copionodontinae from northeastern Brazil (Teleostei: Trichomycteridae). Ichthyological Exploration of Freshwaters, 11(4): 369-375.

Carvalho, E. D., L. R. Marcus, F. Foresti \& V. F. B. Silva. 2005. Fish assemblage attributes in a small oxbow lake (Upper Paraná River Basin, São Paulo State, Brazil): species composition, diversity and ontogenetic stage. Acta Limnologica Brasiliensia, 17(1): 45-56.

Dajoz, R. 1978. Ecologia Geral. Ed. Vozes. Petrópolis, Terceira Edição, 472p.

Fernandes, R., A. A. Agostinho, E. A. Ferreira, C. S. Pavanelli, H. I. Suzuki, D. P. Lima \& L. C. Gomes. 2009. Effects of the hydrological regime on the ichthyofauna of riverine environments of the upper Paraná River floodplain. Brazilian Journal of Biology, 69(2): 669-680.

Higuchi, H., H. A. Britski \& J. C. Garavello.1990. Kalyptodoras bahiensis, a new genus and species of thorny catfish from norteastern Brazil (Siluriformes: Doradidae). Ichthyological Exploration of Freshwaters, 1(3): 219-225.

Jepsen, D. B., K. O. Winemiller \& D. C. Taphorn.1997. Temporal Patterns of Resource Partitioning among Cichla Species in a Venezuela Blackwater River. Journal of Fish Biology, 51: 10851108 .

Latini, A. O. \& M. Petrere. 2004. Reduction of a native fish fauna by alien species: an example from Brazilian freshwater tropical lakes. Fisheries Management and Ecology, 11: 71-79.

Lima, F. C. T. \& P. Gerhard. 2001. A new Hyphessobrycon (Characiformes: Characidae) from Chapada Diamantina, Bahia, Brazil, with notes on its natural history. Ichthyological Exploration of Freshwaters, 12(2): 105-114.

Lin, D. S. C. \& E. P. Caramaschi. 2005. Seasonal and diel stability of limnological parameters and habitat structure in a floodplain lake silted by bauxite tailings (Lago Batata, Pará, Brazil). Amazoniana (Kiel), Kiel, 8(3/4): 185-202.

Lowe-McConnell, R. H. 1999. Estudos ecológicos em comunidades de peixes tropicais. Editora da Universidade de São Paulo, São Paulo, 534p.
Maltchik, L. 1999. Biodiversidade e estabilidade em lagoas do semiárido. Ciência Hoje, Rio de Janeiro, 25(148): 64-67.

Mazzoni, R., N. Fenerich-Verani, E. P. Caramaschi \& R. IglesiasRios. 2006. Stream-dwelling fish communities from an Atlantic rain forest drainage. Brazilian Archives of Biology and Technology, 49(2): 249-256.

Medeiros, E. S. \& L. Maltchik. 2001. Diversity and stability of fishes (Teleostei) in an temporary river of the Brazilian semiarid region. Iheringia, Série Zoologia, 90: 157-166.

Moura, F. B. P. \& J. G. W. Marques. 2007. Conhecimento de pescadores tradicionais sobre a dinâmica espaço-temporal de recursos naturais na Chapada Diamantina, Bahia. Biota Neotropica, 7(3). Available at: http:// www.biotaneotropica.org.br/v7n3/pt.

Pavanelli, C. \& E. P. Caramaschi. 1997. Composition of the ichthyofauna of two small tributaries of the Paraná River, Porto Rico, Paraná State, Brazil. Ichthyological Explorations of Freshwaters, 8(1): 23-31.

de Pinna, M. C. C. 1992. A new subfamily of Trichomycteridae (Teleostei, Siluriformes), lower loricarioid relationships and a discussion on the impact of additional taxa for phylogenetic analysis. Zoological Journal of the Linnean Society, 106: 175229.

Pompeu, P. S. \& A. L. Godinho. 2001. Mudança na dieta da traíra Hoplias malabaricus (Bloch) (Erythrinidae, Characiformes) em lagoas da bacia do rio doce devido à introdução de peixes piscívoros. Revista Brasileira de Zoologia,18(4): 1219-1225.

Reis, R. E., Kullander, S. O. \& C. J. Ferraris-Jr. 2003. Checklist of the Freshwater Fishes of South and Central America. Porto Alegre, Edipucrs, 742p.

Santos, A. C. A. 2003. Caracterização da Ictiofauna do Alto Rio Paraguaçu, com Ênfase nos Rios Santo Antônio e São José (Chapada Diamantina, Bahia). Unpublished Ph.D. Dissertation, Museu Nacional do Rio de Janeiro, 215p.

Santos, A. C. A. \& E. P. Caramaschi. 2007. Composition and Seasonal Variation of the Ichthyofauna from Upper Rio Paraguaçu (Chapada Diamantina, Bahia, Brazil). Brazilian Archives of Biology and Technology, 50: 663-672.

Santos, A. C. A. \& J. L. C. Novaes. 2008. Population Structure of two Astyanax Baird \& Girard, 1854 (Teleostei, Characidae) Species from Upper Paraguaçu River. Brazilian Archives of Biology and Technology, 51: 109-126.

Strahler, A. N. 1957. Quantitative analysis of watershed geomorphology. American Geophysical Union Transactions, 38: 913-920.

Ter Braak, C. J. F. 1991. Update notes: CANOCO Version 3.1. Wageningen, The Netherlands.

Uieda, V. S. 1984. Ocorrência e distribuição dos peixes em um riacho de água doce. Revista Brasileira de Biologia, 44(2): 75-84.

Winemiller, K. O., A. A. Agostinho \& E. P. Caramaschi. 2008. Fish ecology in tropical streams. Pp. 107-146. In: Dudgeon, D. (Ed.). Tropical stream ecology. Amsterdam, Academic Press, 370p.

Zanata, A. M. \& A. Akama. 2004. Myxiops aphos, new characid genus and species (Characiformes: Characidae) from the Rio Lençóis, Bahia, Brazil. Neotropical Ichthyology, 2(2): 45-54.

Zar, J. H. 1984. Biostatistical Analysis. New Jersey, Prentice Hall, $718 \mathrm{p}$.

Zaret, T. M. \& R. T. Paine. 1973. Species Introduction in a Tropical Lake. Science, 182: 445-449. 